\title{
TRADITIONAL MEDICINE: PAST, PRESENT AND FUTURE RESEARCH AND DEVELOPMENT PROSPECTS AND INTEGRATION IN THE NATIONAL HEALTH SYSTEM OF CAMEROON.
}

\author{
Fokunang $\mathrm{CN}^{1 *}$, Ndikum $\mathrm{V}^{1}$, Tabi $O \mathrm{Y}^{1}$, Jiofack, R.B ${ }^{1,2}$, Ngameni $\mathrm{B}^{1}$, Guedje N.M ${ }^{1}$, Tembe- \\ Fokunang, E. ${ }^{1 \text {, , Tomkins }} \mathrm{P}^{4}$, Barkwan $\mathrm{S}^{4}$, Kechia, $\mathrm{F}^{1}$, Asongalem $\mathrm{E}^{1}$, Ngoupayou $\mathrm{J}^{1}$, Torimiro \\ $\mathrm{NJ}^{1,3}$, Gonsu $\mathrm{KH}^{1}$, Sielinou $\mathrm{V}^{1}$, Ngadjui BT ${ }^{1}$, Angwafor III $\mathrm{F}^{1,}$ Nkongmeneck $\mathrm{A}^{2}$, Abena $\mathrm{OM}^{1}$, \\ Ngogang $\mathrm{J}^{2}$, Asonganyi $\mathrm{T}^{1}$, ' Colizzi $\mathrm{V}^{3}$., Lohoue $\mathrm{J}^{2}$, Kamsu-Kom ${ }^{2}$ \\ ${ }^{1}$ Faculty of Medicine and Biomedical Sciences, University of Yaoundé, Cameroon. ${ }^{2}$ Millennium \\ Ecological Museum (MEM), Cameroon Ethno-botany Network (CEN), Yaoundé, Cameroon. \\ ${ }^{3}$ Chantal Biya International Reference Centre (CIRCB), Yaoundé, Cameroon \\ ${ }^{4}$ Athlone Institute of Technology, County Westmeath, Republic of Ireland. \\ *Email:charlesfokunang@yahoo.co.uk
}

\begin{abstract}
Traditional medicine refers to health practices, approaches, knowledge and beliefs incorporating plant, animal and mineral based medicines, spiritual therapies, manual techniques and exercises, applied singularly or in combination to treat, diagnose and prevent illnesses or maintain well-being. In the last decade traditional medicine has become very popular in Cameroon, partly due to the long unsustainable economic situation in the country. The high cost of drugs and increase in drug resistance to common diseases like malaria, bacteria infections and other sexually transmitted diseases has caused the therapeutic approach to alternative traditional medicine as an option for concerted search for new chemical entities (NCE). The World Health Organisation (WHO) in collaboration with the Cameroon Government has put in place a strategic platform for the practice and development of TM in Cameroon. This platform aims at harmonizing the traditional medicine practice in the country, create a synergy between TM and modern medicine and to institutionalize a more harmonized integrated TM practices by the year 2012 in Cameroon. An overview of the practice of TM past, present and future perspectives that underpins the role in sustainable poverty alleviation has been discussed. This study gives an insight into the strategic plan and road map set up by the Government of Cameroon for the organisational framework and research platform for the practice and development of TM, and the global partnership involving the management of TM in the country.
\end{abstract}

Key words: Tradttional medicine, Cameroon.

\section{Introduction}

Cameroon has about $90 \%$ of the African ecosystems which includes; the Sahelian, Sudan, humid tropical forest, afro mountains, coastal and mountain eco-regions. There is a significant diversity of flora and fauna and ranks the 5th in Africa after the republic of Congo, South Africa, Madagascar and Tanzania (Letouzey, 1985; Cunningham, 1993). This rich biological biodiversity is associated with the diversity of the ethnic groups in which each contributes a unique ethno pharmacopoeia and to Cameroon a national therapeutic patrimony, which is the richest in Africa (Houhgton 1995; Nkongmeneck et al., 2007).

Priorities for promoting use of TM in cameroon.

In Cameroon the advent of economic crisis in the late 1980 has created a shift towards consumption of medicinal plant as an increasing practice in herbal medicine. In order to integrate TM into the national healthcare system of Cameroon the WHO in collaboration with the Cameroon Government has put in place strategic route map for TM integration by 2012 (Burkhill, 2000; Ngadjui et al., 2000). The limited scientific evidence about TM/CAM's safety and efficacy as well as other considerations make it important for governments to step into the TM practice, research and development within the frame work of integration into the primary, communal and the national health care system in Cameroon (Noumi, 1984, CIFOR, 2005; Nkongmeneck et al., 2007).

\section{Traditional Medicine platform in Cameroon}

The focus of the implantation strategies for the promotion of traditional medicine research, development and practice in Cameroon is as follows;

1-Formulation of national policy and regulation for the proper use of TM/CAM and its integration into national health care systems in line with the provisions of the WHO strategies on Traditional Medicines; 2-Establish a regulatory mechanisms to control the safety and quality of products and of TM/CAM practice; 3-Create awareness about safe and effective TM/CAM therapies among the public and consumers; 4-Cultivate and conserve medicinal plants to ensure their sustainable use. 5Develop national policies on the evaluation and regulation of TM/CAM practices; 6-Create a stronger evidence base on the 
safety, efficacy and quality of the TAM/CAM products and practices; 7-Ensure availability and affordability of TM/CAM including essential herbal medicines; 8-Promote therapeutically the sound use of TM/CAM by providers and consumers; 9Document traditional medicines and remedies (Nkuinkeu et al., 2007; Jiofack et al 2008)

\section{Interest in medicinal plants and phytomedicines in Cameroon}

Although the main consumers of medicinal plants in Cameroon have been, until recently, the local population, the field has started to attract a number of local and foreign researchers who have discovered the value of traditional healing (Jiofack and Ayissi, 2006; IUCN, 2007) There is active development in TM most especially in the West and Northwest regions of Cameroon where there is an amalgamation of tradi-practitioner to create strong regional associations and organs of operation. Early studies were undoubtedly on ethno-botanical survey and exploration, but since the 90s' the fields of study have expanded to include ethno-pharmacology, phytochemistry, chemistry of natural products, organic synthesis and the usefulness of medicinal and aromatic plants. (Nkuinkeu, 1998; Calapai and Caputi, 2007; Jiofack et al 2009) This interest has increased over the years because of the effort the state has put into natural product research through the University postgraduate research programmes and the Ministry of Research and Innovation's natural products research and development (CERUT, 1999; Nkuinkeu, 2000; Kuete et al., 2007). Some selected medicinal plants for the treatment of malaria under ongoing research for new chemical entities have been shown in figure 1, and 2 the destruction of medicinal plants through abusive harvesting is also highlighted.

The pharmaceutical industry has come to consider traditional medicine as a source for identification of bio-active agents that can be used in the preparation of synthetic medicine. However, they are not looking to study the rare plant species; they want to test the most commonly-used species (LeBeau, 1998; Nguenang et al., 2005; Khan et al., 2009). The valuable medicinal plants are those with the longest track record of use in most or wider locations or distribution in Cameroon (Cunningham, 1993; Nkongmeneck et al., 2007). Many of the more commercial pharmacologically interesting medicinal plant species in use around the world are employed in more than one community, and often in more than one country, for multiple uses (Dooley et al., 2008; Focho et al, 2009).

\section{Cameroon Traditional Herbal Medicine and Public Health Sector}

The majority of African countries and Cameroon in particular, as the case may be, are currently geared towards the privatisation of State corporations and government services. This includes the privatisation of large hospitals where goals of financial independence have precluded the dispensation of free care and free medicine (Nkuinkeu 2000, Mbile et al., 2003, MINSANTE, 2007). Analysis of various national policies related to public health and medicinal plants usage has highlighted some important issues. Among them is the failure to meet basic health conditions due mainly to the following factors in Cameroon: inadequate decentralisation of health services; isolation of some rural communities; and persistence of traditional beliefs regarding pathology (IUCN, 2007). This has led to underutilisation of available services in health centres and high cost of services provided by hospitals in relation to the income of the rural population (Comesky and Sunderland, 2003). Another issue that can be singled out is the absence of local pharmaceutical production. Since the ' 60 s since Cameroon had its independence, the country has not been blessed with a single Drug discovery owned by the state. Purchase of pharmaceutical imported drugs lead to a heavy loss of state revenue, and the development policy has not been focused on available local resources (mainly medicinal plants) (Human and Weerdenburg, 1985; Jiofack and Ayissi, 2006). The current trend of government policy in Cameroon to pay for the health care services shows the inability of government to ensure provision of quality services at an affordable price to everyone and especially to the most vulnerable groups (Mbile et al 2003; Cheek et al., 2004).

In the rural areas of Cameroon, one sometimes travels for several days before finding the nearest dispensary and pharmacy or health clinic for consultation. In addition to loosing working days, transport fares the high cost of medicine must also be taken into consideration. In the past few years, Cameroon joined most of the developing countries in recognising that they do not have the means to provide comprehensive health care like some industrialised countries, and have started taking more interest in promoting the use of traditional remedies (Duncan 1989; Sunderland et al., 2002; Jiofack et al., 2007).

In order to solve the problem of drug shortage or high cost in part, many health-oriented ministries are now encouraging the use of local medicinal plants for disease treatment. The Cameroon ministry of health have established departments of traditional pharmacopoeia within the ministerial organigram so as to implement this policy of TM. Education ministries, the Ministries of Forestry and Wildlife, Research and Innovation have started to introduce conservation and bio-diversity of medicinal plants into their school programmes and the general sensitization of the population (Nkongmeneck et al., 1996; Nguenang et al., 2005. The recent establishment of the Ministries of Environment and Nature Protection and the creation of National Parks, and mapping of protected forest areas, in various parts of the country also demonstrates the political will of the Cameroon governments towards the conservation of nature and the sustainable management of bio-diversity (Vivien et al., 1985; Nkuinkeu et al., 2007).

The lack of health care systems in rural areas forces local people to treat themselves, either by using medicinal plants or by buying high-cost medicine in the rural markets, or still further, going for cheap road side medication, predisposing themselves to health dangers caused by the unknown source of these poor medications (Ndhlala et al., 2009). In the rural areas, as a whole, people begin by treating themselves before going to a traditional practitioner or a modern doctor. Medicinal plants are used at an early stage of the disease at low cost and conveniently replace the indiscriminate consumption of drugs without prescription. (Fokunang et al., 2000; Horan et al., 2003; Oyama et al., 2009).

Many Cameroonians today, especially the rural people and the urban poor, rely on the use of herbal medicine when they are ill. In fact, many rural communities in Africa still have areas where traditional herbal medicine is the major and in some cases the only source of health care available (Bloom et al., 2002; Derita et al., 2009). Thus there can be no doubt about the acceptability and efficacy of herbal remedy within African society. 


\section{How the Western Medical Systems has declined in Cameroon}

In some urban areas the average waiting time at a hospital or clinic to consult a doctor can be as much as 8 hrs. The staff is poorly trained and unmotivated. Many staff members believing they hold superior knowledge, treat patients inconsiderately.-Patients are frequently not told the nature and cause of their illness. -There are inadequate technical services leading to poor quality care. -The treatment costs in clinics are too much, even for state run hospitals and clinics, where consultation and treatment is assumed subsidized. The doctor to patient ratio is approximately 1: 150 per day in the national territory. -Government spends a large proportion of the Per Capita gross national product on western health care (Sofowora, 1982; Bloom et al., 2002; MINSANTE, 2007). -Treatment is divorced from the patient's culture; family and community. Patients are removed from the family and community, stripped of their identity and forced into a sterile hospital setting. The treatment only addresses a patient's biological manifestation of the illness and does not attempt to heal spiritual aspects of illness. This is the place and the role of traditional medical practitioners, in contrast with western medicine, which is technically and analytically base (Tuley, 1997; Samy et al., 2008).

It is difficult to characterize a typical Cameroonian healer, because there are many different kinds, and the cultural diversity and complexity of their practices are encyclopaedic, when considered in detail. Most Cameroonian healers have in common, however, that they describe and explain illness in terms of social interaction and that they act on the belief that religion permeates every aspect of human existence (CERUT, 1999; Tongo, 2003).

Their concepts of health and illness are more comprehensive than those of biomedical doctors. Other prominent features of traditional healers are a deep personal involvement in the healing process, the protection of therapeutic knowledge by keeping it secret, and the fact that they are rewarded for their services. The social context of the therapeutic process requires reciprocity and this payment contributes to the effectiveness of the treatment. (Owira and Ojewole, 2008; Jiofack et al., 2009)

\section{Traditional Practice fee in Cameroon.}

Over the years, the types and methods of payments for traditional healing have changed. In urban settings, practitioners are increasingly demanding monetary payments. Some healers have learnt their trade by undergoing treatment themselves as a patient. The magical inclination of Cameroonian traditional medicine takes nothing away from the fact that some of the healers now are days, are experienced and skilled in biomedical components of their profession. They have an array of biomedical methods at their disposal, ranging from fasting and dieting to herbal therapies and from bathing and massage to surgical procedures (Kokwaro, 1993; Pedersen et al., 2008). Some of the practitioners are graduates who have undergone third level education in the sciences and biomedical sciences. Through hardship, economic downturn and lack of employment in state structures, some educated young Cameroonians have resulted in learning through workshops and short training some ethno-botanical and ethno-pharmacology techniques of medicinal plants. There has been a tendency in Western medical journals to play down the expertise of African healers by predominantly presenting the iatrogenic risks of their traditional therapies. It cannot be denied, of course, that sometimes there is genuine cause for concern (Stafford et al., 2008). It would be unfair, however, to pass judgement on the biomedical merits of African traditional medicine on the basis of its worst outcomes. Instead, African healing should be considered with a sympathetic eye and with emphasis on its best biomedical manifestations (Noumi, 1984; Ngameni et al 2007). Urbanization has increasingly concentrated large numbers of Cameroonian traditional healers and practitioners in an environment where there is stronger competition with the Western medicine. Traditional healing is flourishing in urban settings because it adapts itself to these new surroundings (Robbers et al., 1996). In other words, Cameroonian traditional medicine is more than a static and inflexible institution, which cannot survive the test of time. When a Cameroonian patient is taking an herbal infusion, he expects to benefit from the life force of its ingredients and from the power of his ancestors of any other spirits which may have been invoked. This spiritual significance is more important than the bioactive properties of the remedy.

\section{WHO-Cameroon collaboration to valorize TM.}

The WHO and the Government of Cameroon has signed a convention to draw up a strategic plan for the valorisation to TM in Cameroon. However, despite this programme in progress, the sector is plague with numerous constraints relating to the development of traditional medicine that can be summarised as follows: The lack of institutional support for production and dissemination of key species for cultivation; The low prices paid for traditional medicinal plants by herbal medicine traders and urban herbalists; Lack of appropriate technology for post harvest and pre-processing purposes adapted productively and effectively; Insufficient documentation and scientific experimentation for verification of the herbalist's claims; Lack of preservation of medicinal extracts for extended shelf life (MINSANTE, 2007; Jiofack et al., 2009). The National Strategic Plan for the development and integration of Traditional Medicine in Cameroon and other member countries by the WHO in general and the Africa Union in particular, adhere to the recommendation of the organization to valorise traditional medicine. The political engagement of Cameroon is strongly translated by the official recognition of TM as one of the three main health sectors. The main players of the government convened to put a strategy for the development and integration of traditional medicine in the health system within the framework of the millennium development goal in reducing poverty, morbidity and mortality and sustainable health care development (Tuley de Silva, 1997; MINSANTE, 2007). Medicinal plants are sold locally as plants parts, in powder, dry bark of tress in solutions as shown in Figure 3. 


\section{Organization of Health Care in Cameroon.}

The health system in Cameroon is organised in three levels, represented in the form of pyramid. At the summit is the Central level, the intermediate and the operational level at the base. Three types of structures are integrated into each level namely: the administrative and finance healthcare and community participation (dialogue structure)

The Central Level: The administrative and management structures are represented by the minister of Public Health. The health care structures consist of the three general and reference hospitals, a university teaching hospital and four assimilated central hospitals.

The Intermediate Level: The administrative and management levels consist of the ten regional delegation of public health. The health care structures consist of nine regional hospitals and affiliate structures and the communication structures are made of the regional management commission or regional funds.

The Operational Level: The administrative structures and management structures consist of 173 District health services. The existing structures have 154 district public hospitals, 87 private hospitals, 148 divisional health centre, 1700 health centres and 620 private health centres

The Traditional Medicine Sub-Sectors: Currently Cameroon have at all levels, a non -structured or poorly organized organogramme of TM.

The conference of Regional Governors organized in 1976, by the Ministry of Public

Health for putting an Organizational structure to valorize TM permitted the establishment of 3 organs in Operation such as: 1-The National Commission for TM, in charge of helping the government in the definition and exploitation of TM; 2-Permanent committee of TM in charge of coordinating the research activities and practice of TM; -3-The Medical Institute for the study of medicinal plants in charge of operational research. The Political engagement was validated by the ministerial decision No 031/D/MSP/DS/BT of 31 July 1979 creating and organizing the TM sector within the jurisdiction of the Ministry of Public Health. (MINSANTE, 2007).

The decree of 4th December 1979 organizing the General Delegation for technical and scientific research (DGRST) formerly known as National Office of Technical and Scientific Research (ONAREST)-IMPM was created in 1974. IMPM was charged with the responsibility of drawing up a realizable research programme on TM in order to improve on the health conditions of Cameroonians. The IMPM Institute have four centre of which the Centre for the study of medicinal plants (CEPM) was aimed at elaborating a research programme geared towards the production of drugs and adequate therapeutics using local natural substances. The creation of a traditional medicine unit at the Central Hospitals of Yaoundé, took place in 1981. The organization of the organigramme of the Ministry of Public Health integrating a service for community health and TM under the tutelage of Preventive and Rural medicine happened in 1989. The launching of the first seminar/workshop on TM and Cameroonian pharmacopoeia in the medical school (CUSS), Yaoundé took place from the 10-14th July 1989.

The creation of association of TM enacted by the freedom of association law No 90/053 of 19 December 1990 was followed by a circular note No: D26/NC/MSP/SG/DMPR /DAMPR/SDMR/SSCMT of $16^{\text {th }}$ September 1991 authorizing conventional medicine to collaborate closely where possible with tradi-practitioners. The decree No. 93/215 of 4 August 1993 authorized the reorganization of IMPM and changing the name from. CEPM to CRPMT (Centre de Recherche en Plantes Médicinales et en Médicines Traditionnelles). Then came the prime ministerial decree No 98/405 PM, fixing the homologation strategy to put in the market pharmaceutical products. This led to the creation of the National Drug Commission, which harbours the Commission specialized in Pharmacovigilance and traditional pharmacopoeia; secondly the Commission specialized in Phytotherapy and alternative therapeutic techniques. The presidential decree no 2002/209 of August 2002 organizing the Ministry of Health, put in place a sub-directory in charge of Primary Health, the service of traditional social-health care, made of the office of Ethics and Social Health care deontology, and the bureau of Welfare and Legislation Control. This decree also created a division of Operational Research made up of Scientific Network Cells in charge of support in medicinal plant research (MINSANTE, 2002). Local initiatives are in progress by different NGO's and the state Institutions to train tradi-practitioners the basic conservation techniques and preparation of their herbs within the frame work of quality assurance as shown in Figure 4.

\section{Commemoration of African Traditional Medicine day in Cameroon}

African Traditional Medicine Day is celebrated every year in Cameroon, to sensitized the public on the importance TM. This is a coordinated effort of the government through the Ministry of Health, Ministry of Forestry and Wildlife, Ministry of Research and Innovation and the Ministry of Higher Education, in synergy with tradi-practioners, and medicinal plant researchers involved in contributing to the progress and promotion of traditional medicine in Cameroon. This celebration takes place each year on the $31^{\text {st }}$ August, marking an event where there is collaboration between Traditional and Biomedical Health Practitioners. Each year a theme is given for the celebration, such as "the role of traditional health practitioners in primary health care management” Round table discussions are organized to deal with TM issues, such as the need for synergy between groups, the medical practitioners, ethical issues, health concerns in the practice of TM.

\section{Limiting factors of TM practice collaboration in Cameroon.}

One of the main problems that have caused a slow collaboration between medics and Tradi-pratitioners is the lack of legal framework and official recognition of TM by conventional medicine. (UNESCO, 1994; White, 2000;Tiwari et al., 2009). Tradi-pratitioners are not accepted but tolerated because of the decree that has created a harmonization of the primary health care involving all stake holders. There are no laws guiding the TM practice in Cameroon. The TM sector is volatile and isolated and uncensored, and anyone can enter the trade and this has consequently led to breeding quacks or what is known as "charlatans". There are also competitions in the trade between medics and tradi-practitioners for patients, "thus the saying goes that the winner takes it all”. The party with provisions of the best incentive gets the patients. Lack of proper 
integration of traditional medicine in health care systems: Traditional healers are not attached to bodies like the malaria or HIV/AIDS control committees, they are not involved in the running of services in charge of their work in the ministry of health, are not attached to top research centres, and are rarely given the opportunity to consult in health care institutions as in other countries in Africa. (Mabberly, 1987; Ngadjui, 2000; Kuete et al., 2007; Xu et al, 2008).

We cannot deny the drawbacks of traditional medicine, which include incorrect diagnosis, improper dosage, and low hygiene standards, the secrecy of some healing methods and the absence of written records about the patients (LeBeau, 1998; Teklehaymanot, 2009). Most of the time, the practitioner are unable to have a limit on what they can cure. There is a hit and miss operation going on most of the time. They have very little knowledge on drug-herbal interactions. This had led to severe problems in patients during or after treatment outcomes. Though there is certainly cause for concern, it is unfair to pass judgement on the Cameroon TM healing systems on the basis of their worst outcomes; concerns about romanticising the traditional practices have to be taken seriously (Nkongmeneck et al., 2007; Zhou et al., 2009)

\section{Improving collaboration between Medics and Tradi-Practitioners.}

Traditional medicine should be officially legalised and made part of the official health care system in Cameroon. Intellectual property rights protection should be extended to traditional medicine because some of them have treasured products they have worked with over generation and need to be supported for protection rights. Government should openly and effectively support scientific research into traditional medicine therapies. Traditional medicine should be officially legalised and made part of the official health care system in Cameroon. Government should openly and effectively support scientific research into traditional medicine therapies .

\section{Medicinal Plant Research by State Universities}

Many medicinal plants with antimicrobial activities, anti-inflammatory, anti-oxidant, anticancer, anti-diabetic etc of pharmaceutical importance in developing new chemical entities (NCE), have been phyto-chemically screened and characterized by natural product chemist; and activities tested by biochemist, toxicologist and pharmacologist, in animal models (in vivo), cell lines, pathogen (bacteria, fungi, viruses), parasites (malaria Plasmodium, sleeping sickness (Trypanosome) and many others ((Hepinstall et al., 1992; Kuete et al., 2007; Garrido et al., 2009). Some of these research have produce good results leading to clinical trials that have shown confidence in safety, efficacy and good pharmacokinetics and pharmacodynamics parameters for a potential drug (Pernham, 1996; Mann and Staba, 1998; Asongalem et al., 2008 . The outcome of continuous research has led to some progress in research and development of lead compounds that are under clinical trials in Cameroon from some natural products such as Enantia chlorantha that had produced drugs marketed under the brand name HEPASOR, used for hepatitis virus treatment (Nkongmeneck, 2007). The success story of drugs from medicinal plants commercially available in the market is illustrated in Figure 5.

\section{Hepasor from Natural Plant Enantia chlorantha}

Hepasor is used for the treatment of viral hepatitis family. After submission to the Cameroon drug and pharmacy board for approval, HEPASOR was authorized to be put on the list of essential drugs in Cameroon by the Ministry of Public Health and it is prescribed as an oral solution in a $250 \mathrm{ml}$ bottle (Nkongmeneck, 2007). The hepatitis virus can vary from one geographic region to another and within individual and population. Following the geographic distribution of viral hepatitis, Africa is the most affected continent with a prevalence rate of $12.7 \%$. Viral hepatitis has been a health concern for a long time due to lack of specific efficacious drugs. On the curative front many therapies has been used but most of the drugs have been known to be hepatoprotectant. The stem bark of $E$. chlorantha is very popular for the treatment of viral hepatitis in the forest zones of Cameroon (Jiofack et al., 2009).

The active compound of a complex alkaloid protoberberine isolated from the stem bark of E. chlorantha is constituted of $65 \%$ palmatine, $20 \%$ jatrorrhizine and $15 \%$ cohumbamine. In a natural synergistic manner these alkaloids have shown a curative and preventive function on viral hepatitis. Toxicity test on protoberine active molecule have shown that in addition to its antimicrobial activity, hepasor stimulate blood circulation, regenerates hepatocytes and regulate the normal hepatic functions, thus eliminating megalocytosis.

The therapeutic dose of hepasor is not toxic and the $\mathrm{LD}_{50}$ of protoberberine is $320 \mathrm{mg} / \mathrm{kg}$ of body weight. No side effect was observed on increase in body weight, blood, hepatic, renal tissues and central nervous system. On the contrary secondary beneficial effect was observed: Hepasor is a general tonifiant and appetizer ( $\underline{\text { http://ekolab.free.fr). }}$.

Clinical pilot studies showed improvement of the clinical symptoms on day 7 and there were no symptoms of hepatitis virus after 30 days of treatment. Other biochemical parameters such as bilirubine and transaminase levels were restored to normal level at 60 days of treatment.

\section{Multilateral Research cooperation in Cameroon.}

The Scientific Technical Research Committee of OAN now, AU, (OUA/CSTR) and the agency for Cultural and Technical Cooperation co-financed an ethno-botanical survey in collaboration with the national and international researchers. This had led to the collection and building up of a strong data base on 600 Cameroonian medicinal plant inventory, that has served as the starting point for many chemical, biochemical, toxicology and pharmacological clinical and drug formulation studies (CERUT, 1999; IUCN, 2007). In recent years research laboratories have gone into partnership cooperation with partners of the West, through their various university host institutions, on multidisciplinary research projects in medicinal plants. Some of their findings are in advance stages of clinical trials; most especially in the areas of anti-diabetics, hypertension, anti-oxidant research (Human and Weerdenburg, 1985). 


\section{Local industries producing drugs from medicinal plants.}

There are success stories in medicinal plant research, the journey from the forest, clinics to the pharmacy.Three private industrial firms were created and produces drugs from plant origin that are now sold in pharmacy and drug outlets in Cameroon.

These companies are:

1-LOBOTHERA Laboratory produces the syrup HEPASOR used for treatment of viral hepatitis .

2-KAMSU-KOM Laboratory produces POLA-GASTRAL A-T-200 syrup used for the treatment of stomach ulcer and inflammations.

3-AFRICAPHARM laboratory produces anti -hemorrhoid syrup (syrup Gama)

The organization of traditional medicine practice will bring about a controlled practice and a more responsible and harmonized team of tradi-practitioners. Their integration into the national health sector will bring about putting in place at the disposal of the public standardized traditional medicines, with standard affordable prices as a means of fighting poverty. Tradi-practitioners are integrated and well respected people in their communities. With this standing in society they can play a vital role in the community social health information and health care sensitization.

Cameroon has a rich diversity of flora as a potential to produce primary materials for phyto-medicines. Traditional pharmacopoeia provides avenues for enriching research for new chemical entities that could lead to production of medicines for use in different therapeutic areas such as HIV/AIDS, tuberculosis, malaria, sickle cells and other neglected diseases plaguing the communities and of public health concern.

\section{Ethical issues on TM practice in Cameroon.}

On the ethical point of view there is complete absence of the code of conduct in the practice of TM. This has led to abuse of significant magnitude Uses and sale of products without any instruction or inset and poor labeling. Sales of products without any scientific studies on the active principles and safety (Zhou et al., 2009). Lack of any norms to control what is out in the market for consumption. No formal structure or organization to train tradi-prationers on basic therapeutic techniques and handling of medicinal plant products. Lack of any documentation system, data base for information on medicinal plants, conventions, treaties and decree on medicinal plants (IUCN, 2007; Jiofack et al., 2007).

\section{Economic problems in Cameroon.}

On the economic point of view the over-exploitation of medicinal plants by tradi-practitioners and forest exploiters have impacted a serious consequent on the environment and conservation of species. The lack of political will to support the development the capacities of local industries. The culture of fundamental ethics and patenting is not known or under exploited in Cameroon. The absence of any frame work of collaboration between the TM authors and custodian of knowledge of plants and industrial partners. The low purchasing power of the public on medications, faced with the long financial hardship that the country has witnessed since the early 90's, and the lack of health care facilities in the remote parts of the country (Abegaz, 1999; CIFOR, 2005; Akintonwa et al., 2009)

\section{Fundamental problems.}

Some fundamental problems on plant medicinal research are due to the fact that some indigenous researchers publish their works without any intellectual property rights. The level of protection of innovation and inventions in plants medicines is in total contradiction with the potentials of traditional pharmacopoeia, the knowledge of traditional medicine and dynamism of researchers (Bodeker, 1994; Achoundong et al., 2003). The lack of state of the art equipment to promote research and development, quality control and quality assurance of TM. There is also the problem of training and research that needs to be address. Teaching of TM is not an official institutional programme in training school of health personnel. TM in Cameroon is still essentially under observation and on a personal experience basis, buried in the socio-cultural fabrics and particularly geared towards the ethics and metaphysics beliefs of the African folks (Anonymous, 2000; Agyare et al., 2009). The total lack of spirit for traditional medicine research. The existing bodies or association governing tradipractitioners do not collaborate and are poorly structured and managed. The absence of a national umbrella to coordinate and intervene in the harmonious development of TM.

\section{Herbal-medicinal plant interactions.}

Herbal medicinals are being used by an increasing number of patients who typically do not advise their clinicians of concomitant use. The problem of drug- herbal interaction have been an issue in Cameroon for a long time, because most tradi-practioners are not aware of the fact that they need to be well informed on the interaction potential of their products and some potential medications. Tradi-practitioners need to know what their patients are taking as drugs before any treatment can start (Rose et al., 1990., Asongalem et al., 2008; Samy and Gopalakrisnakone2008). Known or potential drug-herb interactions exist and should be screened for. It has been shown that if used beyond 8 weeks, Echinacea could cause hepatotoxicity and therefore should not be used with other known hepatoxic drugs, such as anabolic steroids, amiodarone, methotrexate, and ketoconazole (Ndhlala et al., 2009). However, Echinacea lacks the 1, 2 saturated necrine ring associated with hepatoxicity of pyrrolizidine alkaloids (Ndhlala et al., 2009) Nonsteroidal anti-inflammatory drugs may negate the usefulness of feverfew in the treatment of migraine headaches (Vivien and Faure, 1985; Stafford et al., 2008). Feverfew, garlic, ginkgo, ginger, and ginseng may alter bleeding time and should not be used concomitantly with warfarin sodium 
(Sonke, 2005). Additionally, ginseng may cause headache, tremulousness, and manic episodes in patients treated with phenelzine sulfate (Sofowora, 1982; White and Edwards, 2000; Garrido et al., 2009). Ginseng should also not be used with estrogens or corticosteroids because of possible additive effects.

\section{Future prospect.}

There is increased interest for search for new chemical entities and the expression of resistance of many drugs available in the market has lead to a shift in paradigm towards medicinal research. There has been an increased interest in the areas of genomics and scientists in Cameroon are looking at the study of this plant not only at cellular level, but at molecular levels. How exposure to cells can regulate gene expression, and selection of biomarkers for different therapeutics endpoint. There is also the prospect of the application of nanotechnology in detecting these NCE at nano-particle. There are ongoing researches on testing medicinal plants for estrogenic properties detected through luciferase genes when exposed to immunofluorescent stained cells.

\section{Conclusion}

Traditional medicine occupies a very important place in health care in the world in general, in Africa and Cameroon in particular: In Cameroon the process to effectively develop TM is in progress due to a favourable integrated environmental, national and international framework set up by the Government.

The Governments should establish the necessary institutional and financial support to promote the potential role of herbal medicine in primary health care delivery. Priority should be given to the development of herbal medicine by means of the following measures: -inventorying and documenting the various medicinal plants and herbs which are used to treat common diseases in each region of Cameroon; -establishing local botanical gardens for the preservation of essential medicinal herbal plants in different parts of each country, in order to ensure a sustainable supply of safe, effective and affordable medicinal herbs; -setting up testing laboratories with adequate facilities for the assessment of the efficacy of medicinal herbs, and establishing dosage norms for the proper administration.

If the Cameroonian society is out to fight poverty by exploring our natural environment, then research should be focused on the use of plants for our welfare for it is said "a healthy man is a wealthy man".

\section{Acknowledgement}

We wish to acknowledge the ministry of Health for making available the strategic information documents on traditional medicine policies in Cameroon. The Millennium Ecological museum for the field research Photographs. The authors also express their gratitude to all the institutions and individuals who gave out any working documents for this review. Our appreciation also goes to all the herbalist medicinal plant vendors and naturopaths for allowing us take photos and providing us with medicinal historical information. The Dean and management of the Faculty of Medicine and Biomedical Sciences University of Yaoundé 1 for their technical support. All the collaborators and partners of the Medical and Pharmacotherapeutic Research Group, University of Yaoundé 1. Finally the Athlone Institute of Technology, Centre for Biopolymer and Bio-molecular Research for their financial support-travel grant for the realization of this work.

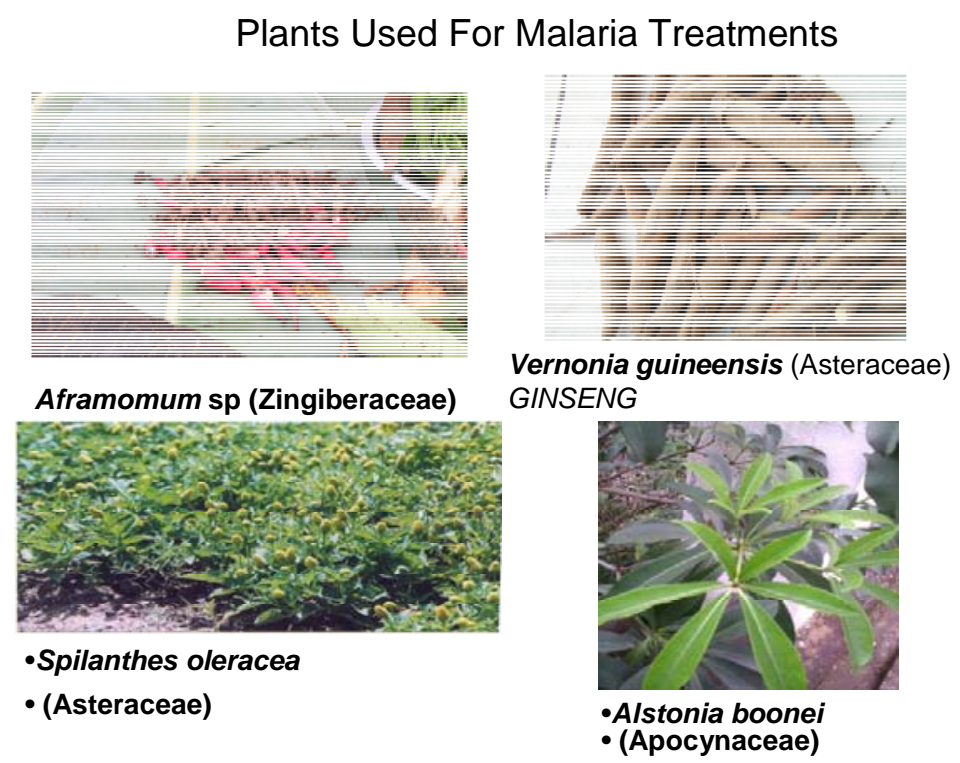

Figure 1: Some selected medicinal plants used from malaria treatments (Courtesy, MEM). 


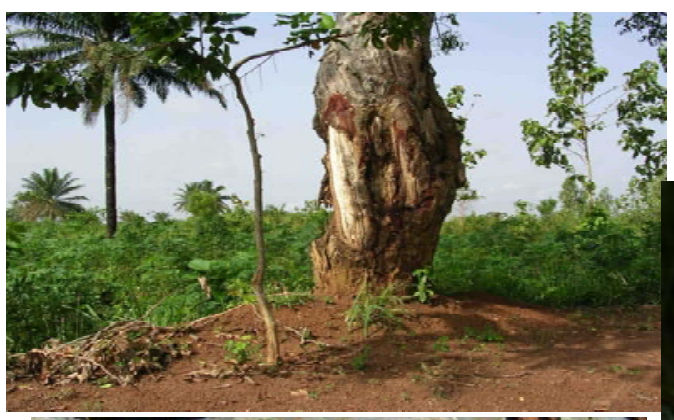

\section{-Destruction of medicinal} plants through abusive harvesting of the bark of tress.
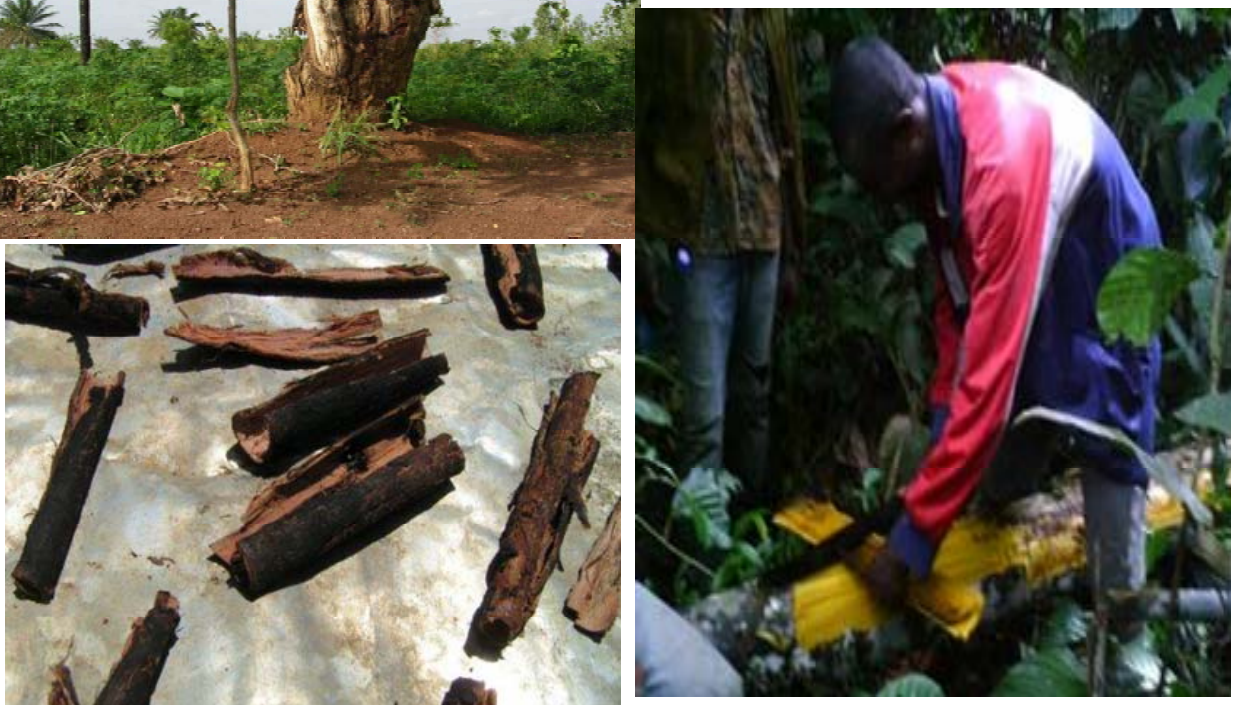

Figure 2: showing destruction of the forest by abusive harvesting. (Courtesy MEM)

\section{Commercialization of medicinal plants}

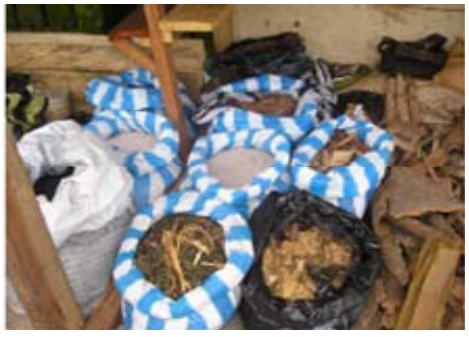

Barks of trees sold in local market



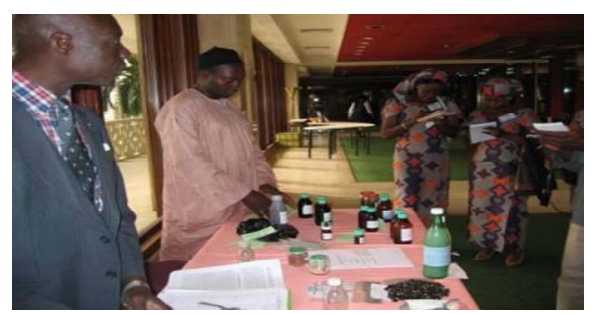

Exhibition sales during African TM Day

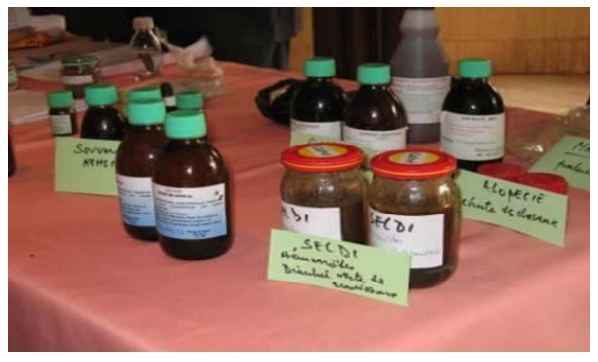

medicinal plants bottled for sale

Figure 3: Medicinal plant products on sale in local markets in Cameroon (courtesy, MEM). 
Participatory Training initiative by the Millennium Ecological Museum (MEM) on basic therapeutic techniques and good preservation practices


Figure 4: Participatory training efforts of tradi-practioners in Cameroon (Courtesy MEM)

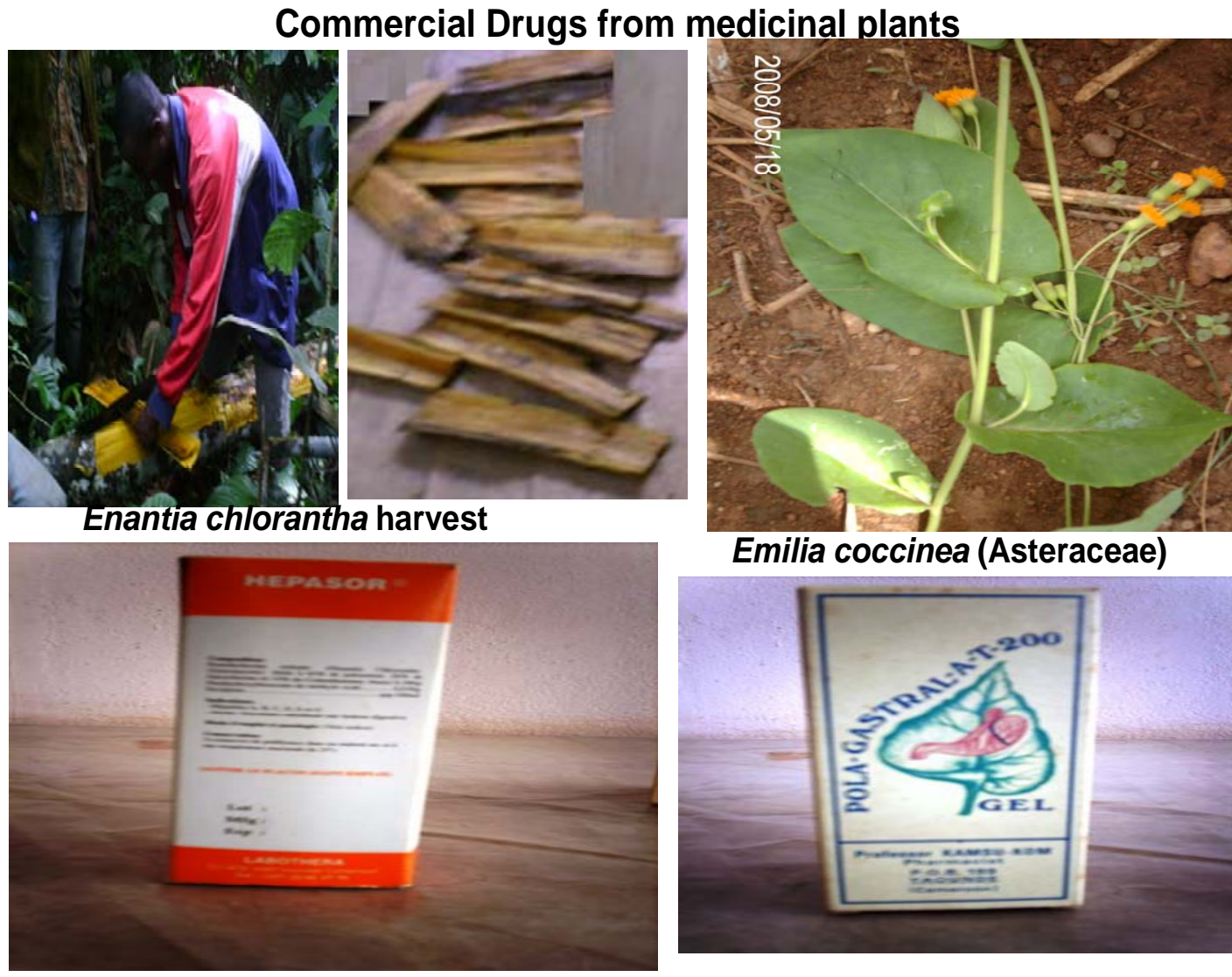

Hepasor use to treat Hepatitis

Pola-Gastral-A-T-200-gastritis/gastralgia

Figure 5: Commercial drugs from local medicinal plants of Cameroon (Courtesy, MEM). 


\section{References}

1. Abegaz, B.M., and Ngadjui B.T.(1999). Chemistry of Marketed Plants of Eastern and Southern Africa Nigeria. J. Nat. Prod.Med, 3: 19-25.

2. Agyare C, Asase A, Lechtenberg M, Niehues M, Deters A, Hensel A. (2009). An ethno-pharmacological survey and in vitro confirmation of ethnopharmacological use of medicinal plants use for wounds healing in BosomtwiAtwima-Kwanwoma area, Ghana, J. Ethnopharmacol, 25; 3:393-403.

3. Anonymous (2000). An overview of logging in Cameroon. A global Forest Watch Cameroon Report. P. 66.

4. Achoundong G, Guedje N, Nkuinkeu R, et Onana JM (2003). Aspects Botaniques et Ecologiques. In Matig OE, Ndoye O, Kengue J, Awono A (eds). Les Fruitiers Comestibles du Cameroun. IPGRI Regional Office for West and Central Africa, Benin. p 204

5. Asongalem EA, Nana P, Foyet HS, Dimo T, Kamtchouing P (2008). Antifertility and fetotoxic activities of Acanthus montanus aqueous extract in Wistar rats. Methods Find Exp Clin Pharmacol.; 30 (7):521-8.

6. Bloom B.S., Retbi A., Dahan S., Jonsson E., 2002. "Evaluation of Randomization Controlled Trial on Complementary and Alternative Medicine”, Int. J. Technol. Assess. Health Care., 16: 13-21.

7. Bodeker, G.(1994). Traditional health knowledge and Public policy. Nature and Resource 30 (2): 5-16.

8. Burkill HM (2000). The Useful Plants of West Tropical Africa, Edition 2 -5), Families S-Z, Royal Botanic Gardens, Kew, 686.

9. CIFOR (2005). Forests and development of Africa. CIFOR in sub-Saharan Africa Internal repor, Yaounde, Cameroon, pp. 116.

10. Calapai G, and Caputi AP. 2007. Herbal medicines: can we do without pharmacologist? Evid Based Complement Alternat Med; 4 ( 1):41-43.

11. CERUT/AIDEnvironment (1999). The Wealth of the Forests in Cameroon. Results of Field Testing a Methodology for the Valuation of Non-timber Forests Products in the North West and South West of Cameroon. p 350.

12. Cheek M, Pollard BJ, Darbyshire I, Onana JM \& Wild C (2004). The Plants of the Kupe Mwanenguba and the Bakossi Mountains, Cameroon: A conservation checklist. p. 258

13. Comesky J, Sunderland TCH, Sunderland-Groves JL (2003). Takamanda: The Biodiversity of an African Rainforest. pp 155-172

14. Duncan WT, Thomas JM, Bromley WA, Mbenkum FT (1989). Korup Ethnobotany Survey. Report. p.176

15. Cunningham, A.B. (1993). African Medicinal Plants: setting priorities at the interface between conservation and primary health care. Working paper 1. UNESCO, Paris 221pp.

16. Derita MG, Leiva ML, Zacchino SA. (2009). Influence of plant part, season of collection and content of the main active constituent, on the antifungal properties of Polygonum acuminatum Kunth. J Ethnopharmacol. 30; 124(3):377-83.

17. Dooley KE, Flexner C, Andrade AS. 2008. Herbal remedies in resource-poor settings: friend or foe? Clin Pharmacol Ther. 84 (1):23.

18. Focho DA, Anjah MG, Nwana FA, Ambo FB (2009). Ethnobotanical survey of trees in Fundong, Northwest Region, Cameroon. J Ethnobiol Ethnomed. 25; 5: 17.

19. Garrido G, Rodeiro I, Hernández I, García G, Pérez G, Merino N, Núñez-Sellés A, Delgado R (2009). In vivo acute toxicological studies of an antioxidant extract from Mangifera indica L. (Vimang). Drug Chem Toxicol. 32 (1):53-8

20. Fokunang, C.N., Ikotun, T., Dixon, A.G.O., Akem, C.N., Tembe-Fokunang, E.A., and Nukenine, E.N., (2000). Efficacy of antimicrobial plant crude extracts on the rowth of Colletrichum gloeosporioides f.sp. manihotis. Pak. J. Biol. Sci., 3 (6):928-932.

21. Horan, I., Clotworthy, M., Fokunang, C.N., Tomkins, P.T., (2003). The development of an in vitro screening strategy for topically applied products. J. Ethnopharmcol., 89: 81-90.

22. Houghton, P.J., (1995). The role of Plants in Traditional Medicine and current therapy. J. Altern. Complem. Med.1: 131-143.

23. Hepinstall S, Awang DV, Dawson BA, Kindach K, Knight DW, May J.1992. Parthenolide content and bioactivity of feverfew: estimates of commercial and authenticated feverfew products. J Pharm Pharmacol; 44:391-395

24. Human, M.E.E., and Weerdenburg, J.C., (1985). «Flore du Cameroun » No 24, MESRES Yaoundé, 485p.

25. IUCN (2007). 2007 IUCN Red List of Threatened Species.http://www.iucnredlist.org.

26. Jiofack T, Kemeuze V, et Pinta J (2007). Les Loranthaceae dans la pharmacopée traditionnelle du groupement Bafou au Cameroun. Cameroon J. Ethnobotany, 2: 29-35.

27. Jiofack T, and Ayissi I (2006). Floristic evaluation of the Upper Nyong valley in Cameroon, Technical report, Cameroon Wildlife Conservation Society. $\mathrm{N}^{\circ}$ (3): 50.

28. Jiofack R, Fokunang C, Kemeuze V, Fongnzossie E, Tsabang Nkuinkeu R, Mapongmetsem P. M, .and Nkongmeneck B. A. 2008. Ethnobotany and phytopharmacopoea of the South-West ethnoecological region of Cameroon J. Med. Plants Res. Vol. 2(8), pp. 197-206,

29. Jiofack, T Ayissi I, Fokunang C, Guedje N and Kemeuze V (2009). Ethnobotany and phytomedicine of the upper Nyong valley forest in Cameroon. Afric. J. Pharm. Pharmacol, 3(4): 144-150.

30. Khan, S., Chattopadhyay, M.T., Sarkar, D., Chatterjee, M.C., Sharma, T., Dey, R., Bag, P, Chakraborti, P. (2009). Recent advancements for the evaluation of anti-viral activities of natural products. N Biotechnol. 25(5):347-68.

31. LeBeau, D, (1998). Urban patients' utilisation of traditional medicine: upholding culture and Tradition, University of Namibia, Sociology Department Windhoek, Namibia, Commission Report vol 11, 33p.

32. Letouzey R (1985). Note of the phytogeographical map of Cameroon with 1/500 000. Always green dense forest wetland domains. Institute of the International vegetation map, Toulouse, France: 63-142.

33. Kokwaro, J.O., (1993). "Medicinal Plants of East Africa," $2^{\text {nd }}$ ed., Kenya Literature, Bureau Box 30022 Nairobi, 
$173 \mathrm{p}$.

34. Kuete, V., Konga, I.S., Ngameni, B., Bigoga, J.D., Watchueng, I., Nzesse, R.K., Etoa, F.X., Ngadjui B.T., Penlap V.B., 2007. Antimicrobial activity of the Methanolic extract, fractions and four flavonoids from the twigs of $D$. angusticornis. J. Ethnopharmacol. 112: 271-277.

35. Mabberley, D.J., 1987. The Plant Book, Cambridge University Press, Cambridge, U.K. 306 p.

36. Mbile P, Tchoundjeu Z, Degrande E, Asaah E and Nkuinkeu R (2003). Mapping the Biodiversity of 'Cinderella trees' in Cameroon. Biodiversity Journal of Life on Earth, 4 (2): 216-228.

37. MINSANT, (2007). Conference for the midterm review of the decade on African traditional medicine, 2001-2010: In Plan Strategique pour l'integration de Medicine traditionelle dans le system national de la santé au Cameroun. Pp.155.

38. Nkongmeneck BA, Mapongmetsem PM, Pinta YV, Nkuinkeu R, Tsabang N, Fongnzossie E, Kemeuze V, Jiofack T, Johnson M, Asaha S, Sakwe C, et Mboufack C (2007). Etat des lieux des plantes médicinales importantes à conserver et des jardins de plantes médicinales à promouvoir. Rapport CEN/OMS/MEM. p. 24.

39. Nkuinkeu R (1998). Plantes Médicinales et Exploitation Forestière. In : Sunderland TCH, Clark LE \& Vantome P. (eds). Les Produits Forestiers Non ligneux en Afrique Centrale. Recherches Actuelles et Perspectives pour la Conservation et le Développement. FAO, Rome, pp 281-285.

40. Nkuinkeu R (2000). Les Oléagineux Non Conventionnels du Cameroun: Inventaire Succinct et Potentialités de Développement. In Kengue J, Kapseu C, Kayem GJ (eds) Actes du 3eme Séminaires International sur la Valorisation du Safoutier et autres Oléagineux Non- Conventionnels. Yaoundé, Cameroon. Presses Universitaires d'Afrique. pp 555-561.

41. Nkuinkeu R, Asaha S, Sakwe C (2007). Use and sustainable development of traditional medicine for the Littoral humid evergreen forest Ethno-Ecological region of Cameroon. CEN Report, p.32

42. Ndhlala AR, Amoo SO, Stafford GI, Finnie JF, Van Staden J. (2009). Antimicrobial, anti-inflammatory and mutagenic investigation of the South African tree aloe (Aloe barberae J Ethnopharmacol. 124:(3):404-8. 6.

43. Ngadjui, B.T., Kouam, S.F., Dongo, E., Kapche, G.W.F., Abegaz, B.M., (2000). Prenylated flavoinoids from the aerial parts of $D$. mannii. J. Ethno Pharmacol. 112:20-36.

44. Ngameni, B., Watchueng, J., Fekam, F.B., Keumedjio, F., Gut J., Abegaz B.M., Rosenthal, P.J., (2007). Antimalaria Prenylated Chalcones from the twigs of D.Barterivar. subtriagularis, Arkivoc 116-123 p.

45. Nguenang GM, Tsabang N, Nkongmeneck B, Fongnzossie E (2005). Simple plan of management of the Community forests in Cameroon :futurology for a the natural resources rational management: case of Enantia chlorantha Oliv. (Annonaceae). Cameroon J. Ethnobot. 1:76-81.

46. Nkongmeneck B, Satabie, Sofowora A, Tamze V et Wirmum (1996). Traditional medicine and pharmacopoia contribution to ethnobotanical and floristic studies in Cameroon. OUA/CSTR. Ed. Lagos Nigeria p. 641.

47. Noumi, E., (1984). Les plantes à épices, à condiments et à aromates du Cameroun. Thése doctorat $3^{\text {eme }}$ cycle, Université de Yaoundé $1166 \mathrm{p}$

48. Mann C, Staba EJ. (1998). The chemistry, pharmacology and commercial formulations of chamomile. In: Craker LE, Simon JE, eds. Herbs, Spices and Medicinal Plants: Recent Advances in Botany, Horticulture and Pharmacology. Vol 1. Binghamton, NY: Hayworth Press Inc; 1986:235-280.

49. Owira PM, Ojewole JA. (2008). 'African potato' (Hypoxis hemerocallidea corm): a plant-medicine for modern and 21st century diseases of mankind?. Phytother Res. 11:211-225.

50. Oyama O, Kosch SG, Burg MA, Spruill TE (2009). Understanding the scope and practice of behavioral medicine in family medicine. Fam Med. 41(8):578-84.

51. Parnham MJ. (1996). Benefit-risk assessment of the squeezed sap of the purple coneflower (Echinacea purpurea) for long-term oral immunostimulation, Phytomedicine 3 (1): 95-102

52. Pedersen ME, Vestergaard HT, Stafford GI, van Staden J, Jäger AK. (2008). The effect of extracts of Searsia species on epileptiform activity in slices of the mouse cerebral cortex. J Ethnopharmacol. 28; (3):538-541.

53. Robbers JE, Speedie MK, Tyler VE. (1996). Terpinoids. In: Robbers JE, Speedie MK, Tyler VE, eds. Pharmacognosy and Pharmacobiotechnology. Baltimore, MD: Williams \& Wilkins: 80-107.

54. Rose KD, Croissant PD, Pariâmes CF, Levin MP. (1990). Spontaneous spinal epidural hematoma with associated platelet dysfunction from excessive garlic ingestion: a case report. Neurosurgery; 26:880-882

55. Samy RP, Gopalakrishnakone P (2008).Therapeutic Potential of Plants as Anti-microbials for Drug Discovery. Evid Based Complement Alternat Med; 24: 115-130.

56. Sunderland TCH, Besong S, Ayeni JSO (2002). Distribution, Utilisation and Stability of the Non-Timber Forests Products of the Takamanda Forest Reserve. cIFOR, BOGOR, INDONESIA, 1-24.

57. Tongo E, Ekwalla M (2003). Nos plantes qui soignent. Centre Spirituel de Rencontre. Tongo Douala, Cameroun. p.131

58. Sofowora, A., (1982). Medicinal plants and traditional medicine in Africa, John Wiley and Sons Limited, Chichester.pp. 321.

59. Sonké B (2005). Dja forest reserve (Cameroon). Floristic and structural studies. Belgium National Botanical Garden, ISBN. 144.

60. Stafford GI, Pedersen ME, van Staden J, Jäger AK. (2008). Review on plants with CNS-effects used in traditional South African medicine against mental diseases. J Ethnopharmacol. 28; (3):513-37.

61. Tiwari BK, Valdramidis VP, O'Donnell CP, Muthukumarappan K, Bourke P, Cullen PJ (2009) . Application of natural antimicrobials for food preservation., J Agric Food Chem. 57(14):5987-6000.

62. Teklehaymanot T (2009). Ethnobotanical study of knowledge and medicinal plants use by the people in Dek Island in Ethiopia. J Ethnopharmacol. 6; 124(1):69-78.

63. Tuley de Silva, (1997). Industrial utilisation of medicinal plants in developing countries, Non-wood Forest Products II: Medicinal plants for forest conservation and healthcare, FAO, Rome, Italy.pp 288.

64. UNESCO, (1994). Traditional Knowledge in Tropical Environment, Nature and Resources. Volume 30, No 1, 
UNESCO, Paris.

65. Vivien J, Faure JJ Central Africa dense forests. (1985). Trees of Cameroon species. French republic, Ministry of foreign relation, Cooperation and development. ACCT. Paris, pp. 392-393

66. White L, Edwards A (2000). Conservation in African rain forest. Method of research. Wildlife Conservation Society, New York. 4444. World Wide Funds-WWF (2000) Site www wwffrance.org.

67. Xu S, Levine M. 2008. Medical residents' and students' attitudes towards herbal medicines: a pilot study. Can J Clin Pharmacol. 2008; 15 (1): 223-236.

68. Zhou Y, Taylor B, Smith TJ, Liu ZP, Clench M, Davies NW, Rainsford KD. (2009). A novel compound from celery seed with a bactericidal effect against Helicobacter pylori. J Pharm Pharmacol.; 61 (8):1067-77 